\title{
Kondisi Sungai di Indonesia Ditinjau dari Daya Tampung Beban Pencemaran: Studi Literatur
}

\author{
Yura Witsqa Firmansyah $^{1^{*}}$, Onny Setiani ${ }^{2}$, Yusniar Hanani Darundiati ${ }^{3}$ \\ ${ }^{1}$ Magister Kesehatan Lingkungan, Fakultas Kesehatan Masyarakat, Universitas Diponegoro, Semarang \\ ${ }^{2,3}$ Departemen Kesehatan Lingkungan, Fakultas Kesehatan Masyarakat, Universitas Diponegoro, Semarang
}

*Koresponden email: firmansyahyura@gmail.com

Diterima: 12 Maret 2021

Disetujui: 25 Maret 2021

\begin{abstract}
The condition of rivers in Indonesia in 2018, 25 rivers were heavily polluted, while in 2019, 38 rivers were heavily polluted. Efforts are needed to determine the carrying capacity of river pollution loads so that they can be used as guidelines for river management. This study aims to provide an overview of the conditions of Indonesia's rivers through a literature review. This literature review uses 10 articles from the Google Scholar database for the period 2014-2020. The rivers under study do not have a pollution load capacity, namely the Code Yogyakarta river, the Bengawan Solo watershed of the Surakarta and Karanganyar sections, the Brantas river in Malang City, the Kupang river, Pekalongan City, the Mahakam river in East Kalimantan, the Winongo river, Sleman Regency, the section of the Brantas river KekepPunden Kota Batu, the segment of the Pesanggrahan river of the City; Garang river, Central Java Bedung river, Denpasar City. Most of the parameters that exceed the loading capacity of the entire river are BOD, COD, TSS, nitrite, nitrate, phosphate, and ammonia. The source of pollution in most rivers is unidentified (certain and uncertain sources of pollution). Generally, river management efforts are not carried out in an optimal manner to maintain water quality and condition .
\end{abstract}

Keywords: Code river, Bengawan Solo river, Brantas river, Kupang river, pollution load capacity, Indonesia river

\begin{abstract}
Abstrak
Kondisi sungai di Indonesia pada tahun 2018 sebanyak 25 sungai tercemar berat sementara tahun 2019 bertambah menjadi 38 sungai dengan status tercemar berat. Perlu upaya penentuan daya tampung beban pencemaran sungai agar bisa dijadikan pedoman dalam pengelolaan sungai. Penelitian ini bertujuan untuk memberikan gambaran kondisi sungai di Indonesia melalui studi literatur. Studi literatur ini menggunakan 10 artikel dari database google scholar dalam kurun waktu 2014-2020. Adapun sungai yang dikaji sudah tidak memiliki daya tampung beban pencemaran yaitu sungai Code Yogyakarta, DAS Bengawan Solo ruas Surakarta dan Kabupaten Karanganyar, sungai Brantas ruas Kota Malang, sungai Kupang Kota Pekalongan, sungai Mahakam Provinsi Kalimantan Timur, sungai Winongo Kabupaten Sleman, sungai Brantas ruas Kekep-Punden Kota Batu, sungai Pesanggrahan segmen Kota; sungai Garang Jawa Tengah dan sungai Bedung, Kota Denpasar. Parameter yang paling banyak melampaui daya tampung beban pencemaran dari keseluruhan sungai adalah BOD, COD, TSS, nitrit, nitrat, fosfat dan amonia. Sumber pencemaran pada sebagian besar sungai tidak teridentifikasi (sumber pencemaran tertentu dan tak tentu). Umumnya upaya pengelolaan sungai dilakukan tidak optimal untuk menjaga kualitas air dan status mutu air sungai.
\end{abstract}

Kata Kunci: sungai Code, sungai Bengawan Solo, sungai Brantas, sungai Kupang, daya tampung beban pencemaran, sungai Indonesia

\section{Pendahuluan}

Air merupakan salah satu komponen penting untuk manusia dan makhluk hidup lainnya sebagai sumber penghidupan. Sumber air salah satunya dapat berasal dari air permukaan yang dapat didefinisikan sebagai air yang terdapat diatas permukaan tanah baik dalam kondisi diam atau mengalir misalnya sungai. Ketersediaan air permukaan berupa sungai di Indonesia memiliki volume yang sangat banyak. Sungai sangat sering dimanfaatkan sebagai penyuplai air minum, kebutuhan irigasi sawah, budidaya perikanan, pariwisata hingga transportasi.

Kualitas air sungai di Indonesia masih dikategorikan belum cukup baik. Pada Tahun 2019, Indonesia memiliki 98 sungai, dengan sebaran cemaran sungai sebanyak 54 sungai tercemar ringan, 6 sungai dengan cemaran ringan-sedang, dan sebanyak 38 sungai mengalami cemaran berat [1]. Kondisi 
sungai pada tahun 2019 di Indonesia lebih buruk jika dibandingkan pada tahun 2018. Pada tahun 2018, terdapat 97 sungai dengan sebaran cemaran sebanyak 67 sungai tercemar ringan, sungai dengan cemaran sedang berjumlah 5 serta sebanyak 25 sungai dengan cemaran berat [1].

Adapun sungai yang dimasukan dalam kajian literatur ini dan yang sudah tidak memiliki daya tampung beban pencemaran adalah sungai Code Yogyakarta (segmen Gondolayu, Sayidan dan Ngoto); sungai DAS Bengawan Solo ruas Surakarta dan Kabupaten Karanganyar (segmen jembatan Bacem, X, Curug, Ringroad, dan Kemiri); sungai Brantas ruas Kota Malang (segmen jembatan Pendem, UMM, Soehat, Pasar Burung Malang, Kutho Bedah, Kol Sugiono, dan Bumi Ayu); sungai Kupang Kota Pekalongan (segmen hulu kelurahan Kuripan Lor, Kelurahan Kuripan Lor, Landung Sari, Pesindon, dan Krapyak Kidul); sungai Mahakam Provinsi Kalimantan Timur (segmen Beloro, Tenggarong, Kalamur, Samarinda, Palaran, dan Anggana); sungai Winongo Kabupaten Sleman (segmen Karanggawang, Denggung, Jatimulyo, Jlagran, Tamansari, Dongkelan, Bakulan, dan Mojo); sungai brantas ruas KekepPunden Kota Batu (segmen Sidomulyo 2); sungai Pesanggrahan segmen Kota Depok (segmen Bedahan, Meruyung, Cinangka, Limo, Pondok Cabe Udik, dan Cinere); sungai Garang Jawa Tengah (segmen dusun Lempuyangan, jembatan Pramuka, jembatan Tinjomoyo, Tugu Suharto, dusun Polaman, jembatan Gisik Sari, jembatan Lemah Gempal, jembatan RE. Martadinata) sungai Bedung, Kota Denpasar .

Pencemaran air dapat didefinisikan dengan masuk atau dimasukkannya makhluk hidup, energi, zat dan atau komponen lainnya sehingga melebihi baku mutu yang telah ditetapkan [2]. Pencemaran air sungai dapat terjadi dari dua sumber yaitu sumber tertentu dan tak tentu, sumber tertentu berasal dari limbah aktivitas industri dan limbah domestik terpadu. Sedangkan untuk sumber limbah tak tentu bersumber dari kegiatan pemukiman, pertanian, dan transportasi. Pencemaran air dapat terjadi berupa cemaran fisik, biologi dan kimia (kimia organik dan anorganik) yang ketika melebihi baku mutu memiliki dampak bahaya bagi biota perairan atau manusia jika dipergunakan untuk kehidupan.

Sungai memiliki daya dukung yang berbeda-beda, daya dukung sungai dijadikan sebagai telaah untuk melihat kemampuan sungai dalam mendukung kehidupan manusia atau makhluk hidup lainnya. Daya dukung sungai ditentukan dari selisih daya tampung beban pencemaran dengan beban pencemaran itu sendiri [3]. Sedangkan daya tampung beban pencemaran sungai diartikan sebagai kapasitas sungai dalam menampung pencemaran yang masuk [4]. Beban pencemaran dapat diklasifikasikan menjadi dua, beban pencemaran maksimum adalah beban pencemaran yang diperbolehkan di suatu sungai didasarkan pada peruntukannya [5]. Selanjutnya, beban pencemaran aktual merupakan beban pencemaran yang dihasilkan pada saat eksisting [5]. Metode QUAL2Kw merupakan pemodelan yang sering digunakan untuk analisis daya tampung sungai. QUAL2Kw merupakan pengembangan dari QUAL2E yang digunakan dalam estimasi nilai beban pencemaran pada setiap segmen sungai [3]. Penelitian ini bertujuan untuk menggambarkan kondisi sungai di Indonesia ditinjau dari daya tampung beban pencemaran berbasis literature review.

\section{Metode Penelitian}

Penelitian ini merupakan literature review, dengan kajian jurnal yang didapatkan dari database google scholar dalam kurun waktu 2014-2020. Ruang lingkup kajian merupakan pencemaran sungai di Indonesia ditinjau dari daya tampung beban pencemaran. Artikel ini akan menggambarkan kondisi sungai di Indonesia, namun tidak keseluruhan sungai dikaji dalam literatur hanya dalam publikasi 6 tahun yang digunakan sebagai kajian literatur. Tabel 1 merupakan daftar jurnal yang digunakan dalam artikel review ini.

Tabel 1. Daftar jurnal yang menjadi materi review

\begin{tabular}{|c|c|c|c|c|c|}
\hline No & Pengarang & Judul & Publisher & Tahun & Ref \\
\hline 1. & $\begin{array}{l}\text { Marlina N., } \\
\text { Brontowiyono W., } \\
\text { Chasna R. }\end{array}$ & $\begin{array}{l}\text { Analisis Kualitas Air dan Daya } \\
\text { Tampung } \\
\text { Qungai dengan Metode } \\
\text { QUALKw (Studi Kasus: Sungai Code, } \\
\text { Yogyakarta) }\end{array}$ & $\begin{array}{l}\text { Jurnal Serambi } \\
\text { Engineering }\end{array}$ & 2020 & [6] \\
\hline 2. & $\begin{array}{l}\text { Dani T., Suripin, } \\
\text { Sudarno. }\end{array}$ & $\begin{array}{l}\text { Analisis Daya Tampung Beban Cemar } \\
\text { di DAS Bengawan Solo Segmen Kota } \\
\text { Surakarta dan Kabupaten Karanganyar } \\
\text { dengan Model QUAL2Kw }\end{array}$ & $\begin{array}{l}\text { Jurnal Ilmu } \\
\text { Lingkungan }\end{array}$ & 2015 & [7] \\
\hline 3. & $\begin{array}{l}\text { Fajaruddin H.A., } \\
\text { Sholichin M., Prayogo } \\
\text { B.T. }\end{array}$ & $\begin{array}{l}\text { Studi Penentuan Daya Tampung Beban } \\
\text { Pencemaran Sungai Brantas Ruas Kota } \\
\text { Malang dengan Menggunakan Paket } \\
\text { Program QUAL2Kw }\end{array}$ & $\begin{array}{l}\text { Jurnal Mahasiswa } \\
\text { Jurusan Teknik } \\
\text { Pengairan }\end{array}$ & 2019 & [8] \\
\hline
\end{tabular}




\begin{tabular}{|c|c|c|c|c|c|}
\hline 4. & $\begin{array}{l}\text { Pohan S.A.D., } \\
\text { Budiyono, Syafrudin. }\end{array}$ & $\begin{array}{l}\text { Analisis Kualitas Air Sungai Guna } \\
\text { Menentukan Peruntukan di Tinjau dari } \\
\text { Aspek Lingkungan }\end{array}$ & $\begin{array}{l}\text { Jurnal Ilmu } \\
\text { Lingkungan }\end{array}$ & 2016 & [9] \\
\hline 5. & $\begin{array}{l}\text { Jumiati Y., Mislan, } \\
\text { Subagiada K. }\end{array}$ & 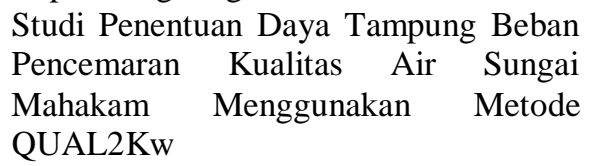 & $\begin{array}{l}\text { Jurnal Geosains Kutai } \\
\text { Basin }\end{array}$ & 2020 & [10] \\
\hline 6. & $\begin{array}{l}\text { Richa V.A., Haribowo } \\
\text { R., Prayogo T.B. }\end{array}$ & $\begin{array}{l}\text { Studi Penentuan Daya Tampung Beban } \\
\text { Pencemaran Hulu Sungai Brantas Ruas } \\
\text { Kekep-Punden Kota Batu dengan } \\
\text { Menggunakan Aplikasi QUAL2Kw }\end{array}$ & $\begin{array}{l}\text { Jurnal Mahasiswa } \\
\text { Jurusan Teknik } \\
\text { Pengairan }\end{array}$ & 2017 & [12] \\
\hline 7. & $\begin{array}{l}\text { Marlina N., Kasam, } \\
\text { Juliani A. }\end{array}$ & $\begin{array}{l}\text { Evaluasi Daya Tampung terhadap } \\
\text { Beban Pencemaran Menggunakan } \\
\text { Model Kulitas Air (Studi Kasus : Sungai } \\
\text { Winongo) }\end{array}$ & $\begin{array}{l}\text { Jurnal Inovasi dan } \\
\text { Kewirausahaan }\end{array}$ & 2015 & [13] \\
\hline 8. & $\begin{array}{l}\text { Komarudin M., } \\
\text { Hariyadi S., } \\
\text { Kurniawan B. }\end{array}$ & $\begin{array}{l}\text { Analisis Daya Tampung Beban } \\
\text { Pencemaran Sungai Pesanggrahan }\end{array}$ & $\begin{array}{l}\text { Jurnal Pengelolaan } \\
\text { Sumberdaya Alam dan } \\
\text { Lingkungan }\end{array}$ & 2015 & [14] \\
\hline 9. & $\begin{array}{l}\text { Trilaksono G., } \\
\text { Sudarno, Handayani } \\
\text { D.S. }\end{array}$ & $\begin{array}{l}\text { Studi Penentuan Daya Tampung Beban } \\
\text { Pencemaran Air Sungai Melalui } \\
\text { Pendekatan Software QUAL2E dan } \\
\text { Metode Neraca Massa (Studi Kasus : } \\
\text { Sungai Garang, Jawa Tengah) }\end{array}$ & $\begin{array}{l}\text { Program Studi Teknik } \\
\text { Lingkungan FT } \\
\text { UNDIP }\end{array}$ & 2014 & [15] \\
\hline 10. & $\begin{array}{l}\text { Santiari, M., Nuarsa, } \\
\text { I. W., Suyasa, I.W.B. }\end{array}$ & $\begin{array}{l}\text { Penetapan Daya Tampung Beban } \\
\text { Pencemaran Sungai Badung di Desa } \\
\text { Pamogan }\end{array}$ & $\begin{array}{l}\text { Ecotrophic : Jurnal } \\
\text { Ilmu Lingkungan } \\
\text { (Journal of } \\
\text { Environmental } \\
\text { Science) }\end{array}$ & 2016 & [23] \\
\hline
\end{tabular}

\section{Hasil dan Pembahasan Sungai Code, Yogyakarta}

Kajian penelitian dilakukan di Sungai Code, sungai yang terdiri dari bagian hulu didominasi dengan aktivitas pertanian, aktivitas pemukiman mendominasi pada dibagian tengah dan bagian hilir didominasi oleh aktivitas persawahan, pemukiman, industri dan restoran [6]. Pada bulan September Tahun 2016 kajian dilakukan di sungai Code menggunakan model QUAL2Kw [6]. Dengan kajian 6 segmentasi sungai Conde, segmentasi 1 (T1) Ngentak-Gondolayu, segmentasi 2 (T2) Gondolayu-Sayidan, segmentasi 3 (T3) Sayidan-Keparakan, segmentasi 4 (T4) Keparakan-Tungkak, segmentasi 5 (T5) Tungkak-Ngoto, segmentasi 6 (T6) Ngoto-Wonokromo [6].

Segmentasi Ngentak memiliki debit 2,340 $\mathrm{m}^{3} / \mathrm{s}$, dengan kedalaman 0,413 meter, lebar 24,37 serta kecepatan aliran $1,071 \mathrm{~m} / \mathrm{s}$. Segmentasi kedua adalah Gondolayu dengan debit $2,510 \mathrm{~m}^{3} / \mathrm{s}$, dengan kedalaman 0,188 meter, lebar 12,5 meter dan kecepatan aliran 1,071 m/s. Ketiga adalah segmentasi Sayidan, dengan debit 3,649 m³ $/ \mathrm{s}$, kedalaman 0,363 meter, memiliki lebar 30,1 meter serta kecepatan aliran $0,333 \mathrm{~m} / \mathrm{s}$. Segmentasi kelima adalah Keparakan, dengan debit $4,050 \mathrm{~m}^{3} / \mathrm{s}$, memiliki kedalaman 0,350 meter, lebar 42,67 meter dan kecepatan aliran 0,271 m/s. Keenam adalah segmentasi Ngoto, dengan debit air 3,160 m³ $/ \mathrm{s}$, kedalaman 0,205 meter, memiliki lebar 19,5 meter, dan kecepatan aliran 0,197 m/s. Dan segmentasi terakhir adalah Wonokromo, debit aliran 3,070 $\mathrm{m}^{3} / \mathrm{s}$, kedalaman 0,218 meter, lebar 23,8 meter dan kecepatan aliran 0,592 m/s [6].

Kualitas air Sungai Conde Yogyakarta yang menjadi kajian adalah TSS, ammonia, dan fosfat. Beban pencemaran parameter TSS di Sungai Code keseluruhan segmentasi (T1-T6) telah melampaui daya tampung. Dengan hasil perhitungan sebagai berikut, T1 -381,49 kg/jam; T2 -622,77 kg/jam; T3 4,23 kg/jam; T4 -603,05 kg/jam; T5 -1042,57 kg/jam; dan T6 -914,84 [6]. Hasil hitung beban pencemaran parameter amonia, hanya T2; T3; dan T6 yang melebihi daya tampung dengan masing-masing nilai, -2,18 $\mathrm{kg} / \mathrm{jam} ;-1,55 \mathrm{~kg} / \mathrm{jam} ;-0,17 \mathrm{~kg} / \mathrm{jam}$. Sementara untuk parameter fosfat, beban pencemaran yang melebihi daya tampung hanya berada pada segmentasi 3 (T3) yaitu $-0,12 \mathrm{~kg} / \mathrm{jam}$. Segmentasi 2 dan 3 merupakan area perkotaan yang sudah tercemar oleh aktivitas manusia, industri, rumah tangga, dan lain-lain. Tabel 2 Memperlihatkan analisis kondisi Sungai Code Yogyakarta. 
Tabel 2. Analisis kondisi Sungai Code, Yogyakarta

\begin{tabular}{ll}
\hline \multicolumn{1}{c}{ Analisis } & \multicolumn{1}{c}{ Keterangan } \\
\hline $\begin{array}{l}\text { Parameter yang } \\
\text { melebihi baku } \\
\text { mutu }\end{array}$ & $\begin{array}{l}\text { Amonia (segmen Gondolayu, Sayidan dan Ngoto), fosfat (segmen } \\
\text { Keparakan) dan TSS (semua segmen) }\end{array}$ \\
$\begin{array}{l}\text { Sumber } \\
\text { pencemaran }\end{array}$ & $\begin{array}{l}\text { 1. Amonia dalam air dapat bersumber dari air seni dan tinja, oksidasi } \\
\text { zat organik secara mikrobiologi, air buangan dari industri serta }\end{array}$ \\
& aktivitas masyarakat [16]. Konsentrasi amonia yang tinggi dalam \\
& air, menyebabkan terjadinya penurunan oksigen terlarut, gangguan \\
& fungsi fisiologi, serta metabolisme seperti respirasi [17]. \\
2. Fosfat dalam air dapat bersumber dari limbah industri, hotel, pupuk, & limbah domestik dan penguraian bahan organik lainnya [18]. \\
& Fosfat dalam air dapat menyebabkan eutrofikasi yang \\
& menyebabkan biota air mati [18]. \\
3. TSS dalam air sungai terjadi karena meningkatnya padatan \\
tersuspensi sehingga menyebabkan sinar matahari terhalang masuk \\
kedalam sungai berdampak pada proses fotosintesis terganggu \\
[19]. \\
Upaya pengelolaan sungai dapat dilakukan dengan perbaikan IPAL \\
jika sumber pencemaran dari limbah kegiatan industri. Pembuatan \\
IPAL domestik secara terpadu atau komunal untuk pencegahan \\
sumber limbah dari kegiatan rumah tangga, pertanian-perkebunan, dan \\
transportasi. Penggunaan teknologi bioremediasi dapat digunakan \\
dalam upaya pengelolaan pencemaran air limbah.
\end{tabular}

\section{Daerah Aliran Sungai (DAS) Bengawan Solo, Segmen Surakarta dan Kabupaten Karanganyar}

Bengawan Solo merupakan sungai terpanjang yang ada di pulau Jawa, dengan panjang sungai mencapai 600 kilometer. Kajian penelitian dilakukan pada segmentasi Surakarta dan Kabupaten Karanganyar dengan wilayah kajian Kota Surakarta, Sukoharjo, dan Kabupaten Karanganyar [7]. Kota Surakata merupakan salah satu daerah perkotaan dengan padat penduduk. Sedangkan Kabupaten Karanganyar didominasi oleh sektor pertanian dan industri-industri besar [7]. Lokasi kajian penelitian dilakukan pada 4 segmen, segmen 1 (jembatan Bacem-jembatan X); segmen 2 (jembatan X-Curug); segmen 3 (jembatan Curug-Ringroad); dan segmen 4 (jembatan Ringroad-Kemiri) dengan lokasi titik pengambilan sampling 10 titik, dengan sebaran 5 titik pada input anak sungai atau drainase, sedangkan 5 lagi pada badan air Sungai Bengawan Solo. Adapun 5 titik pada input anak sungai atau drainase adalah Kali Pepe, Kali Ngringo, Kali Anyar, Kali Pengok, dan Kali Sroyo. Sedangkan 5 titik pada badan sungai Bengawan Solo diambil dari jembatan Bacem, Kp. Sewu, Jurug, Ringroad, dan Kemiri [7].

Kualitas air sungai Bengawan Solo yang dikaji adalah pH, DO, BOD, dan COD. Parameter BOD pada badan Sungai Bengawan Solo secara keseluruhan melebihi baku mutu yang ditetapkan pada kelas 2 dengan nilai berurutan sebagai berikut, $11,47 \mathrm{mg} / \mathrm{l} ; 10,75 \mathrm{mg} / \mathrm{l} ; 15,14 \mathrm{mg} / \mathrm{l} ; 15,91 \mathrm{mg} / \mathrm{l} ; 9,25 \mathrm{mg} / \mathrm{l}$. Parameter BOD yang diambil pada badan sungai Bengawan Solo lokasi titik sampling jembatan Kp.Sewu dan jembatan Kemiri dengan nilai 36,65 mg/l; 33,31 mg/l melebihi baku mutu kelas 2 [7].

Ditinjau dari parameter BOD dan COD, untuk baku mutu kelas 2 keseluruhan segmen telah melebihi daya tampung sungai. Segmen 1 (jembatan Bacem-X) untuk parameter BOD diperlukan penurunan beban cemar sebesar 15.559,69 kg/hari [7]. Untuk segmen 2 (jembatan X-Curug) diperlukan penurunan beban cemar sebesar 16.186,48 kg/hari [7]. Pada segmen 3 (jembatan Curug-Ringroad) $24.075,23 \mathrm{~kg} / \mathrm{hari}$ beban cemar diperlukan penurunan. Segmen 4 (jembatan Ringroad-Kemiri) membutuhkan penurunan beban cemar sebesar 81.871,91 kg/hari. Sedangkan parameter COD segmen yang melebihi daya tampung sungai berdasarkan baku mutu kelas 2 adalah, segmen 1;3 dan 4. Segmen 1 (jembatan Bacem-X) diperlukan penurunan beban cemar sebesar 30,207,81 kg/hari. Sebesar 8.305,21 $\mathrm{kg} /$ hari pada segmen 3 (jembatan Curug-Ringroad) diperlukan penurunan. Dan untuk segmen 4 (jembatan Ringroad-Kemiri) diperlukan penurunan beban cemar sebesar $31.338,07 \mathrm{~kg} / \mathrm{hari}$ [7]. Tabel 3 memperlihatkan analisis kondisi Daerah Aliran Sungai (DAS) Bengawan Solo, Segmen Surakarta dan Kabupaten Karanganyar. 
Tabel 3. Analisis kondisi Daerah Aliran Sungai (DAS) Bengawan Solo, Segmen Surakarta

Dan Kabupaten Karanganyar

\begin{tabular}{|c|c|}
\hline Analisis & Keterangan \\
\hline \multirow[t]{2}{*}{$\begin{array}{l}\text { Parameter yang } \\
\text { melebihi baku } \\
\text { mutu }\end{array}$} & $\begin{array}{l}\text { 1. BOD (segmen 1 perlu dilakukan penurunan sebesar } 15.559,69 \\
\mathrm{~kg} / \mathrm{hari} \text {; segmen } 2 \quad 16.186,48 \mathrm{~kg} / \mathrm{hari} \text {; segmen } 3 \\
\mathrm{~kg} / \mathrm{hari} \text {; segmen } 481.871,91 \mathrm{~kg} / \mathrm{hari} \text { ) }\end{array}$ \\
\hline & $\begin{array}{l}\text { 2. COD (segmen } 1 \text { perlu dilakukan penurunan sebesar } 30,207,81 \\
\mathrm{~kg} / \mathrm{hari} \text {; segmen } 38.305,21 \mathrm{~kg} / \mathrm{hari} \text {; dan segmen } 431.338,07 \\
\mathrm{~kg} / \mathrm{hari} \text { ) segmen } 2 \text { masih memenuhi baku mutu yang telah } \\
\text { ditetapkan }\end{array}$ \\
\hline \multirow[t]{2}{*}{$\begin{array}{l}\text { Sumber } \\
\text { pencemaran }\end{array}$} & $\begin{array}{l}\text { 1. BOD dalam air meningkat disebabkan karena ada pencemaran } \\
\text { dari limbah domestik, pertanian dan peternakan [7]. Tingginya } \\
\text { BOD dalam air akan mengakibatkan DO dalam air rendah, } \\
\text { sehingga biota air akan kekurangan oksigen [20]. }\end{array}$ \\
\hline & $\begin{array}{l}\text { 2. COD dalam air meningkat disebabkan karena adanya } \\
\text { pencemaran dari limbah domestik, pertanian dan peternakan [7]. } \\
\text { COD adalah kebutuhan oksigen terlarut dalam air untuk } \\
\text { menguraikan bahan-bahan organik [21]. Nilai COD yang tinggi } \\
\text { menyebabkan ekosistem perairan terganggu seperti ikan dan } \\
\text { tumbuhan air tidak dapat hidup dengan baik [21]. }\end{array}$ \\
\hline Pengelolaan sungai & $\begin{array}{l}\text { Pencemaran yang terjadi pada DAS Bengawan Solo, Segmen } \\
\text { Surakarta dan Kabupaten Karanganyar didominasi sumber } \\
\text { pencemaran tak tentu. Diperlukan pengelolaan pada sumber tak tentu } \\
\text { sebesar } 70-80 \% \text { dengan pembuatan IPAL pada rumah tangga, industri } \\
\text { pertanian dan peternakan. }\end{array}$ \\
\hline
\end{tabular}

\section{Sungai Brantas, Ruas Kota Malang}

Kajian daya tampung beban pencemaran dilakukan di sungai Brantas ruang Kota Malang. Dengan parameter kualitas air yang diukur adalah BOD, COD, DO, TSS, pH, dan nitrat. Lokasi kajian penelitian dilakukan dari jembatan Pendem hingga jembatan Bumi Ayu dengan total jarak 21,57 kilometer. Terbagi menjadi 7 segmen, segmen 1 (jembatan Pendem); segmen 2 (jembatan UMM); segmen 3 (jembatan Soehat); segmen 4 (jembatan Pasar Burung Malang; segmen 5 (jembatan Kutho Bedah); segmen 6 (jembatan Kol Sugiono); jembatan 7 (jembatan Bumi Ayu) [8].

Konsentrasi parameter BOD pada semua segmen melebihi baku mutu yang ditetapkan pada Peraturan Pemerintah nomor 82 Tahun 2001. Sedangkan konsentrasi parameter TSS hanya pada segmen 1 (jembatan Pendem) dan segmen 2 (jembatan UMM) yang melebihi baku mutu pada regulasi yang sama [8]. Perhitungan beban pencemaran pada segmen 2 (jembatan UMM) juga sangat tinggi untuk semua parameter. Dengan nilai hitung, BOD 152,669 kg/hari; TSS 609,846 kg/hari; COD 995,976 kg/hari. Sementara itu, segmen 2 (jembatan UMM) memiliki daya tampung sebagai berikut, BOD 127,164 kg/hari; TSS 584,340 kg/hari; dan untuk COD 910,958 kg/hari [8]. Kondisi Sungai Brantas, Ruas Kota Malang hasil analisisnya dapat dilihat pada Tabel 4.

Tabel 4. Analisis kondisi Sungai Brantas, ruas Kota Malang

\begin{tabular}{lll}
\hline Analisis & Keterangan \\
\hline $\begin{array}{l}\text { Parameter yang } \\
\text { melebihi baku } \\
\text { mutu }\end{array}$ & 1. & $\begin{array}{l}\text { Parameter BOD telah melebihi baku mutu pada semua segmen; } \\
\text { sedangkan } \\
\text { Parameter TSS melebihi baku mutu pada segmen 1 dan segmen } \\
\text { 2. }\end{array}$ \\
pumber & 1. & $\begin{array}{l}\text { BOD dalam air meningkat disebabkan karena ada pencemaran } \\
\text { dari sumber tertentu dan sumber tak tentu. Tingginya BOD } \\
\text { dalam air akan mengakibatkan DO dalam air rendah, sehingga } \\
\text { biota air akan kekurangan oksigen [20]. } \\
\text { COD dalam air meningkat disebabkan karena adanya } \\
\text { pencemaran dari sumber tertentu dan sumber tak tentu. COD } \\
\text { adalah kebutuhan jumlah oksigen terlarut dalam air untuk } \\
\text { menguraikan bahan-bahan organik [21]. Nilai COD yang tinggi } \\
\text { menyebabkan ekosistem perairan menjadi terganggu seperti ikan } \\
\text { dan tumbuhan air tidak dapat hidup dengan baik [21]. }\end{array}$ \\
\hline
\end{tabular}




$\begin{aligned} \text { Pengelolaan sungai } & \text { Pencemaran yang terjadi pada sungai Brantas ruas Kota Malang } \\ & \text { disebabkan sumber pencemaran tak tentu dan tertentu. Diperlukan } \\ & \text { pengelolaan pada sumber tak tentu sebesar 70-80\% dengan pembuatan } \\ & \text { IPAL pada rumah tangga, industri pertanian dan peternakan. Serta } \\ & \text { perlu upaya pemantauan terhadap efektivitas dan efisiensi IPAL dari } \\ & \text { industri. }\end{aligned}$

\section{Sungai Kupang, Kota Pekalongan}

Kajian daya tampung beban pencemaran dilakukan di Sungai Kupang, Kota Pekalongan. Sungai Kupang salah satu sungai di Kota Pekalongan yang dialiri oleh limbah domestik dan limbah industri. Kajian dilakukan pada 6 titik lokasi sebagai berikut, titik 1 (hulu Kelurahan Kuripan Lor); titik 2 (Kelurahan Kuripan Lor); titik 3 (Kelurahan Landung Sari); titik 4 (Kelurahan Pesindon); titik 5 (Kelurahan Krapyak Kidul); dan titik 6 (Kelurahan Panjang Wetan).

Kualitas air yang diuji adalah parameter temperatur, TSS, pH, DO, BOD, COD, kromium dan fosfat. Namun parameter yang dikaji dalam beban pencemaran adalah TSS, BOD, dan COD. Hasil perhitungan daya tampung beban pencemaran TSS, beban pencemaran pada titik 1 hingga titik 5 masih memenuhi baku mutu beban pencemaran didasarkan pada sungai kelas I dan II; sedangkan pada titik 6 (Kelurahan Panjang Wetan) telah melebihi daya tampung sungai kelas II mengacu pada regulasi Peraturan Pemerintah nomor 82 Tahun 2001 dengan penurunan nilai beban pencemaran sebesar 1198,00 $\mathrm{kg} / \mathrm{hari}$ [9]. Parameter BOD didapatkan hasil perhitungan daya tampung beban pencemaran dari keseluruhan titik 1-6 telah melebihi daya tampung sungai dengan kategori sungai kelas I dan II [9]. Begitu juga dengan parameter COD, dari keseluruhan titik didapatkan hasil perhitungan daya tampung beban pencemaran melebihi baku mutu sungai kelas I; namun jika dibandingkan berdasarkan daya tampung beban pencemaran baku mutu sungai kelas II titik 1 dan 2 masih memenuhi baku mutu, untuk titik 3-6 telah melebihi daya tampung beban pencemaran sungai. Titik 3-6 diperlukan penurunan beban pencemaran sebagai berikut, titik $32126 \mathrm{Kg} /$ hari; titik 4 454,46 Kg/hari; titik 5 372,28 Kg/hari; dan titik 6 2655,44 Kg/hari [9]. Hasil analisis yang dilakukan terhadap kondisi Sungai Kupang, Kota Pekalongan dapat dilihat pada Tabel 5.

Tabel 5. Analisis kondisi Sungai Kupang, Kota Pekalongan

\begin{tabular}{|c|c|}
\hline Analisis & Keterangan \\
\hline $\begin{array}{l}\text { Parameter yang } \\
\text { melebihi baku } \\
\text { mutu }\end{array}$ & $\begin{array}{l}\text { 1. Parameter TSS pada titik } 6 \text { (kelurahan Pajang Wetan) melebihi } \\
\text { baku buku yang ditetapkan. Diperlukan penurunan beban } \\
\text { pencemaran TSS sebesar } 1198,00 \mathrm{~kg} / \mathrm{hari} \text {. } \\
\text { 2. Parameter BOD telah melebihi baku mutu sungai kelas I dan II } \\
\text { pada semua titik. } \\
\text { 3. Parameter COD telah melebihi baku mutu sungai kelas I pada } \\
\text { semua titik }\end{array}$ \\
\hline $\begin{array}{l}\text { Sumber } \\
\text { pencemaran }\end{array}$ & $\begin{array}{l}\text { 1. BOD dalam air dapat terjadi dikarenakan proses pembusukan } \\
\text { atau degradasi oleh mikroorganisme [22]. Beban pencemaran } \\
\text { BOD pada sungai Kupang meningkat karena sepanjang aliran } \\
\text { dari hulu hingga hilir sungai mendapatkan buangan dari sumber } \\
\text { pencemaran tertentu dan tak tentu. } \\
\text { TSS dan COD dalam air sungai Kupang disebabkan karena } \\
\text { cemaran limbah industri dan pemukiman di sekitar sungai. }\end{array}$ \\
\hline Pengelolaan sungai & $\begin{array}{l}\text { Upaya pengelolaan sungai Kupang pada segmen } 1 \text { dan } 2 \text { lebih } \\
\text { dilakukan pendekatan kepada masyarakat. Perlu edukasi ke } \\
\text { masyarakat sekitar sungai untuk tidak membuang sampah, dan limbah } \\
\text { domestiknya ke sungai. Sedangkan pada segmen } 3 \text { perlu adanya } \\
\text { monitoring pada industri, terkait dengan keberadaan IPAL, fungsi, } \\
\text { efektivitas serta efisiensinya. }\end{array}$ \\
\hline
\end{tabular}

\section{Sungai Mahakam, Provinsi Kalimantan Timur}

Sungai Mahakam memiliki panjang 920 kilometer dan memiliki kuantitas air sebesar $325.380 \mathrm{~m}^{3}$ yang terletak di provinsi Kalimantan Timur. Kajian penelitian di Sungai Mahakam terbagi menjadi 8 segmen, yaitu segmen 1 (Beloro); segmen 2 (Tenggarong); segmen 3 (Kalamur); segmen 4 (Samarinda); 
segmen 5 (Palaran); dan segmen 6 (Anggana). Parameter kualitas air yang diuji adalah BOD, COD, dan TSS [10].

Parameter TSS didapatkan hasil perhitungan daya tampung beban pencemaran minimum sebesar $1,972 \mathrm{Kg} / \mathrm{hari}$; sedangkan nilai maksimumnya adalah $0,931 \mathrm{Kg} / \mathrm{hari}$ [10]. Parameter BOD memiliki nilai daya tampung beban pencemaran minimum sebesar $1,728 \mathrm{Kg} /$ hari dan maksimum sebesar $0,86 \mathrm{Kg} / \mathrm{hari}$ [10]. Untuk parameter COD nilai daya tampung beban pencemaran minum sebesar $2,592 \mathrm{Kg} / \mathrm{hari}$ sedangkan untuk nilai maksimumnya adalah $1,296 \mathrm{Kg} /$ hari [10]. Hasil analisis yang dilakukan terhadap kondisi Sungai Mahakam, Provinsi Kalimantan Timur dapat dilihat pada Tabel 6.

Tabel 6. Analisis kondisi Sungai Mahakam, Provinsi Kalimantan Timur

\begin{tabular}{|c|c|}
\hline Analisis & Keterangan \\
\hline $\begin{array}{l}\text { Parameter yang } \\
\text { melebihi baku } \\
\text { mutu }\end{array}$ & $\begin{array}{l}\text { 1. Parameter TSS melebihi baku mutu yang ditetapkan pada semua } \\
\text { segmen, sehingga diperlukan pengurangan sebesar } 0,996 \mathrm{~kg} / \mathrm{hari} \text {. } \\
\text { 2. Parameter BOD diperlukan upaya pengurangan sebesar } 0,868 \\
\mathrm{~kg} / \text { hari. } \\
\text { 3. Parameter COD diperlukan upaya pengurangan sebesar } 1,296 \\
\mathrm{~kg} / \text { hari. }\end{array}$ \\
\hline $\begin{array}{l}\text { Sumber } \\
\text { pencemaran }\end{array}$ & Sumber pencemaran tertentu \\
\hline Pengelolaan sungai & $\begin{array}{l}\text { Diperlukan upaya reduksi sebesar } 30 \% \text { dari sumber pencemaran } \\
\text { tertentu pada saat musim kemarau }\end{array}$ \\
\hline
\end{tabular}

\section{Sungai Brantas, Ruas Kekep-Punden, Kota Batu}

Kota Batu memiliki jumlah penduduk sebanyak 202.319 jiwa pada Tahun 2016. Dengan rata-rata tingkat pertumbuhan penduduk mencapai $0,91 \%$. Kondisi pertumbuhan penduduk dikhawatirkan penyebab terjadinya alih fungsi lahan dibagian hulu DAS Sungai Brantas serta penurunan kualitas air [11]. Kajian daya tampung beban pencemaran dilakukan pada, segmen 1 (jembatan Kekep); segmen 2 (jembatan Sidomulyo 1); segmen 3 (Sidomulyo 2); segmen 4 (jembatan Metro); dan segmen 5 (jembatan Punden) [11]. Parameter yang diukur adalah TSS, DO, BOD, COD, pH dan suhu.

Nilai konsentrasi dari parameter DO, BOD, COD dan TSS melebihi baku mutu yang ditetapkan dengan kategori kelas I air [12]. Nilai beban pencemaran dengan simulasi 2 (beban kosong) segmen 3 (jembatan Sidomulyo 2) memiliki nilai yang besar dengan nilai TSS 676,512 kg/hari; BOD 45,1008 $\mathrm{kg} / \mathrm{hari}$; COD 225,504 kg/hari [12]. Beban pencemaran yang masuk ke Sungai Brantas telah melampaui daya tampung sungai yang ada, pada segmen 3 (jembatan Sidomulyo 2) sebagai segmen tertinggi dengan nilai daya tampung beban pencemaran TSS 455,328 kg/hari dan COD 68,7744 kg/hari, sedangkan untuk BOD disemua segmen memiliki nilai daya tampung beban pencemaran yang sama yaitu $1,0368 \mathrm{~kg} / \mathrm{hari}$ [12]. Tabel 7 memperlihatkan hasil analisis Kondisi Sungai Brantas, Ruas Kekep-Punden, Kota Batu.

Tabel 7. Analisis kondisi Sungai Brantas, Ruas Kekep-Punden, Kota Batu

\begin{tabular}{ll}
\hline \multicolumn{1}{c}{ Analisis } & \multicolumn{1}{c}{ Keterangan } \\
\hline $\begin{array}{l}\text { Parameter yang } \\
\text { melebihi baku } \\
\text { mutu }\end{array}$ & TSS (pada segmen 3), BOD (pada segmen 3), COD (pada segmen 3) \\
$\begin{array}{l}\text { Sumber } \\
\text { pencemaran }\end{array}$ & 1. $\quad \begin{array}{l}\text { Sumber limbah tertentu, limbah dari kegiatan industri dan } \\
\text { pembuangan limbah domestik secara terpadu } \\
\text { Sumber limbah tak tentu, limbah dari kegiatan pertanian, } \\
\text { pemukiman dan transportasi }\end{array}$ \\
Pengelolaan sungai & $\begin{array}{l}\text { Diperlukan upaya reduksi sebesar 30-50\% dari sumber pencemaran } \\
\text { tertentu pada saat musim kemarau }\end{array}$ \\
\hline
\end{tabular}

\section{Sungai Winongo, Kabupaten Sleman}

Sungai Winongo merupakan anak Sungai Opak dengan panjang sungai utama berkisar 53,83 km. Hulu dari Sungai Winongo adalah Kecamatan Turi, Kecamatan Sleman, Kecamatan Mlati, dan Kecamatan Gamping serta daerah aliran sungai (DAS) Winongo memiliki luasan $118 \mathrm{~km}^{2}$ 13]. Kajian penelitian dilakukan pada segmentasi, TS 1-TS 2 (Karanggawang-Denggung); TS 2-TS 3 (Denggung- 
Jatimulyo); TS 3-TS 4 (Jatimulyo-Jlagran); TS 4-TS 5 (Jlagran-Tamansari); TS 5-TS 6 (TamansariDongkelan); TS 6- TS 7 (Dongkelan-Bakulan); TS 7-TS 8 (Bakulan-Mojo).

Parameter yang diukur adalah $\mathrm{BOD}, \mathrm{DO}, \mathrm{pH}$, dan suhu dengan masing masing nilai rata-rata 16 $\mathrm{mg} / \mathrm{l} ; 2,4 \mathrm{mg} / \mathrm{l} ; 7$; dan $26^{\circ} \mathrm{C}$ [13]. Didapatkan hasil perhitungan daya tampung beban pencemaran sungai telah melebihi kapasitas tampung dari sungai Brantas [13]. Segmen 3 (Jatimulyo) menjadi segmen yang paling besar tidak bisa menampung beban pencemaran dengan nilai $-202.823 \mathrm{~kg} / \mathrm{hari}$ [13]. Hasil analisis yang dilakukan terhadap kondisi Sungai Winongo, Kabupaten Sleman terlihat pada Tabel 8.

Tabel 8. Analisis kondisi Sungai Winongo, Kabupaten Sleman

\begin{tabular}{ll}
\hline \multicolumn{1}{c}{ Analisis } & \multicolumn{1}{c}{ Keterangan } \\
\hline Parameter yang & \multicolumn{2}{l}{ Beban pencemaran BOD pada semua segmen telah melebihi baku } \\
melebihi baku & mutu. Diperlukan upaya penurunan sebagai berikut, \\
mutu & 1. $\quad$ Segmen 1 diperlukan penurunan $1.788 \mathrm{~kg} / \mathrm{hari}$ \\
& 2. $\quad$ Segmen 2 diperlukan penurunan $64.51 \mathrm{~kg} / \mathrm{hari}$ \\
& 3. $\quad$ Segmen 3 diperlukan penurunan $202.823 \mathrm{~kg} / \mathrm{hari}$ \\
& 4. $\quad$ Segmen 4 diperlukan penurunan $57.485 \mathrm{~kg} / \mathrm{hari}$ \\
& 5. $\quad$ Segmen 5 diperlukan penurunan $34.800 \mathrm{~kg} / \mathrm{hari}$ \\
& 6. $\quad$ Segmen 6 diperlukan penurunan $67.652 \mathrm{~kg} / \mathrm{hari}$ \\
& 7. $\quad$ Segmen 7 diperlukan penurunan $108.184 \mathrm{~kg} / \mathrm{hari}$
\end{tabular}

Sumber Sumber pencemaran limbah di sungai Winongo tidak terindentifikasi.

pencemaran Namun kemungkinan sumber pencemaran tertentu dari limbah dari kegiatan industri dan pembuangan limbah domestik secara terpadu dan sumber tak tentu limbah dari kegiatan pertanian, pemukiman dan transportasi.

Pengelolaan sungai Perlu adanya identifikasi lebih terhadap sumber cemaran di area sungai Winongo, untuk melakukan pengelolaan sungai.

\section{Sungai Pesanggrahan, Segmen Kota Depok}

Sungai Pesanggrahan mengaliri wilayah Kabupaten Bogor, Kota Depok, dan Kota Tangerang serta juga mengaliri daerah di Jawa Barat, sampai ke Jakarta Selatan, Jakarta Barat, dan Jakarta Utara. Kajian penelitian daya tampung beban pencemaran Sungai Pesanggrahan dilakukan pada segmentasi, head water (Kabupaten Bogor, Kota Depok); segmen 1 (Sawangan, Bedahan); segmen 2 (Sawangan, Meruyung); segmen 3 (Cinangka, Meruyung); segmen 4 (Cinangka, Limo); segmen 5 (Cinangka, Pondok Cabe Udik, Cinere). Parameter yang diukur adalah COD, BOD, dan TSS.

Total perhitungan beban pencemaran di sungai Pesanggrahan telah melebihi daya tampung beban pencemaran sungai berdasarkan klasifikasi kelas II [14]. Dengan sebaran besar nilai beban pencemaran COD $59.930 \mathrm{~kg} / \mathrm{hari}$; TSS $48.975 \mathrm{~kg} / \mathrm{hari}$; dan BOD $8.257 \mathrm{~kg} / \mathrm{hari}$. Sedangkan daya tampung sungai untuk parameter COD $58.280 \mathrm{~kg} / \mathrm{hari}$; TSS $49.085 \mathrm{~kg} / \mathrm{hari}$; dan BOD $8.111 \mathrm{~kg} / \mathrm{hari}$ [14]. Hasil analisis yang dilakukan terhadap Kondisi Sungai Pesanggrahan, Segmen Kota Depok dapat dilihat pada Tabel 9.

Tabel 9. Analisis kondisi Sungai Pesanggrahan, segmen Kota Depok

\begin{tabular}{|c|c|}
\hline Analisis & Keterangan \\
\hline $\begin{array}{l}\text { Parameter yang } \\
\text { melebihi baku } \\
\text { mutu }\end{array}$ & $\begin{array}{l}\text { 1. Diperlukan upaya penurunan beban pencemaran BOD sebesar } \\
146 \mathrm{~kg} / \mathrm{hari} \\
\text { 2. Diperlukan upaya penurunan beban pencemaran COD sebesar } \\
1.650 \mathrm{~kg} / \mathrm{hari} \\
\text { 3. Diperlukan upaya penurunan beban pencemaran TSS sebesar } \\
110 \mathrm{~kg} / \mathrm{hari}\end{array}$ \\
\hline $\begin{array}{l}\text { Sumber } \\
\text { pencemaran }\end{array}$ & $\begin{array}{l}\text { Sumber pencemaran limbah di Sungai Winongo tidak terindentifikasi. } \\
\text { Namun kemungkinan sumber pencemaran tertentu dari limbah dari } \\
\text { kegiatan industri dan pembuangan limbah domestik secara terpadu } \\
\text { dan sumber tak tentu limbah dari kegiatan pertanian, pemukiman dan } \\
\text { transportasi. }\end{array}$ \\
\hline Pengelolaan sungai & $\begin{array}{l}\text { Perlu adanya identifikasi lebih terhadap sumber cemaran di area } \\
\text { Sungai Winongo, untuk melakukan pengelolaan sungai. Misalnya } \\
\text { menggunakan sistem informasi geografis (SIG). }\end{array}$ \\
\hline
\end{tabular}




\section{Sungai Garang, Jawa Tengah}

Daerah aliran sungai (DAS) Garang meliputi Kabupaten Semarang (hulu), Kabupaten Kendal (hulu dan tengah), Kota Semarang (tengah dan muara). DAS Garang berbentuk kipas, yang mana bagian hulu berukuran lebar sedangkan hilirnya berukuran sempit kondisi ini mengakibatkan akumulasi air yang cukup besar pada bagian hilir sehingga potensial terjadi banjir khususnya di Sungai Garang. Kajian penelitian dilakukan pada 8 titik, titik 1 (dusun Lempuyangan); titik 2 (jembatan Pramuka); titik 3 (jembatan Tinjomoyo); titik 4 (Tugu Suharto); titik 5 (dusun Polaman); titik 6 (jembatan Gisik Sari); titik 7 (jembatan Lemah Gempal); dan titik 8 (jembatan RE. Martadinata).

Parameter yang diukur adalah, DO, BOD, COD, amonia, nitrat, nitrit, dan fosfat. Hasil simulasi daya tampung beban pencemaran yang didapatkan, pada aliran minimum (musim kemarau) kemudian dibandingkan dengan baku mutu Peraturan Pemerintah nomor 81 Tahun 2001. Sungai Garang dapat menampung beban pencemaran BOD pada kelas III; COD pada kelas IV; nitrat pada kelas I; nitrit pada kelas I, II, III; fosfat pada kelas III; sedangkan amonia belum memenuhi debit minimum dan maksimum pada regulasi tersebut [15]. Kondisi saat debit maksimum (musim penghujan), beban pencemaran BOD memenuhi daya tampung beban pencemaran sungai pada kelas III; COD pada kelas IV; nitrat pada kelas I; nitrit pada kelas I,II,III; dan fosfat pada kelas III [15]. Setiap segmentasi di Sungai Garang memiliki baku mutu kelas air yang berbeda-beda [15]. Hasil analisis kondisi Sungai Garang, Jawa Tengah dapat dilihat pada Tabel 10.

Tabel 10. Analisi kondisi Sungai Garang, Jawa Tengah

\begin{tabular}{|c|c|}
\hline Analisis & Keterangan \\
\hline $\begin{array}{ll}\text { Parameter } & \text { yang } \\
\text { melebihi } & \text { baku } \\
\text { mutu } & \end{array}$ & 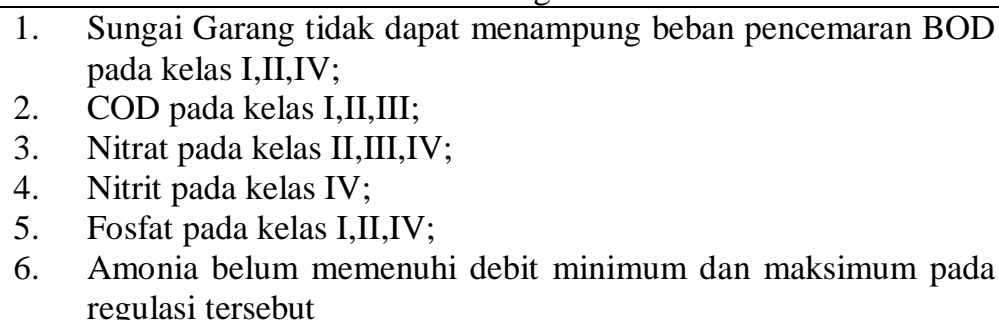 \\
\hline $\begin{array}{l}\text { Sumber } \\
\text { pencemaran }\end{array}$ & $\begin{array}{l}\text { Sumber pencemaran limbah di sungai Garang tidak teridenfikasi. } \\
\text { Namun kemungkinan sumber pencemaran tertentu dari limbah dari } \\
\text { kegiatan industri dan pembuangan limbah domestik secara terpadu } \\
\text { dan sumber tak tentu limbah dari kegiatan pertanian, pemukiman dan } \\
\text { transportasi. }\end{array}$ \\
\hline Pengelolaan sungai & $\begin{array}{l}\text { Perlu adanya identifikasi lebih terhadap sumber cemaran di area } \\
\text { sungai Garang, untuk melakukan pengelolaan sungai. Misalnya } \\
\text { menggunakan sistem informasi geografis (SIG). }\end{array}$ \\
\hline
\end{tabular}

\section{Sungai Badung, Desa Pamogan, Kota Denpasar}

Sungai Badung salah satu bagian dari daerah aliran sungai (DAS) Badung dengan bagian hulu dari kecamatan Abiansemal kabupaten Badung Kota Denpasar. Kajian penelitian parameter BOD dan COD dilakukan di beberapa ruas sungai Badung [23]. Adapun lokasi kajian yang dilakukan pada 3 ruas dapat dilihat pada Tabel 11.

Tabel 11. Lokasi ruas sampling

\begin{tabular}{rllll}
\hline \multirow{2}{*}{ Ruas } & \multicolumn{4}{c}{ Koordinat } \\
\cline { 2 - 5 } & \multicolumn{2}{c}{ Hulu } & \multicolumn{2}{c}{ Hilir } \\
\cline { 2 - 5 } & Latitude & Longitude & Latitude & Longitude \\
\hline 1 & $8^{\circ} 41^{\prime} 13.23^{\prime \prime}$ & $115^{\circ} 11^{\prime} 55.50^{\prime \prime}$ & $8^{\circ} 41^{\prime} 40.42^{\prime \prime}$ & $115^{\circ} 11^{\prime} 46.05^{\prime \prime}$ \\
2 & $8^{\circ} 41^{\prime} 40.42^{\prime \prime}$ & $115^{\circ} 11^{\prime} 46.05^{\prime \prime}$ & $8^{\circ} 42^{\prime} 59.13^{\prime \prime}$ & $115^{\circ} 11^{\prime} 21.94 "$ \\
3 & $8^{\circ} 42^{\prime} 59.13^{\prime \prime}$ & $115^{\circ} 11^{\prime} 21.94^{\prime \prime}$ & $8^{\circ} 43^{\prime} 17.87^{\prime \prime}$ & $115^{\circ} 11^{\prime} 13.44^{\prime \prime}$ \\
\hline
\end{tabular}

Nilai konsentrasi BOD telah melebihi baku mutu yang ditetapkan, sedangkan untuk parameter COD dan TSS masih dibawah baku mutu. Beban pencemaran masing-masing parameter tersebut adalah, BOD 419,97 kg/hari; COD 865,66 kg/hari; dan TSS 160,70 kg/hari. Sedangkan daya tampung beban pencemaran BOD telah melebihi baku mutu, untuk COD dan TSS sebesar $1686.53 \mathrm{~kg} / \mathrm{hari}$ dan 4743.36 
kg/hari [23]. Tabel 12 memperlihatkan hasil analisis kondisi Sungai Badung, Desa Pamogan, Kota Denpasar.

Tabel 12. Analisis kondisi Sungai Badung, Desa Pamogan, Kota Denpasar

\begin{tabular}{lll}
\hline \multicolumn{1}{c}{ Analisis } & \multicolumn{4}{c}{ Keterangan } \\
\hline $\begin{array}{l}\text { Parameter yang } \\
\text { melebihi baku } \\
\text { mutu }\end{array}$ & $\begin{array}{l}\text { Parameter BOD telah melampaui daya tampung beban } \\
\text { pencemaran pada semua ruas } \\
\text { Parameter COD masih memiliki daya tampung beban } \\
\text { pencemaran sebesar } 1686.53 \mathrm{~kg} / \mathrm{hari}\end{array}$ \\
& $\begin{array}{l}\text { Parameter TSS masih memiliki daya tampung beban pencemaran } \\
\text { sebesar 4743.36 kg/hari. }\end{array}$ \\
$\begin{array}{l}\text { Sumber } \\
\text { pencemaran }\end{array}$ & $\begin{array}{l}\text { Pencemaran sungai Badung bersumber dari tak tentu (daerah } \\
\text { pemukiman dan pertanian) dan sumber tertentu (aliran dari hulu) }\end{array}$ \\
Pengelolaan sungai & $\begin{array}{l}\text { Diperlukan IPAL untuk daerah pemukiman dan pertanian agar } \\
\text { mengurangi beban pencemaran BOD pada Sungai Badung }\end{array}$ \\
\hline
\end{tabular}

\section{Proteksi dan Mitigasi Sungai}

Upaya proteksi sungai adalah suatu tindakan yang dilakukan untuk melindungi perubahan kualitas sungai akibat pencemaran yang masuk [24]. Sedangkan upaya mitigasi sungai adalah suatu tindakan untuk mencegah berubahnya kualitas air sungai untuk peruntukannya [25]. Upaya proteksi dan mitigasi sungai dapat dilakukan dengan kerjasama multisektor [26]. Pertama dari kelompok masyarakat, diperlukan pemahaman dan kesadaran masyarakat yang tinggal didaerah aliran sungai untuk tidak melakukan pembuangan limbah, sampah, dan kegiatan domestik lainnya ke badan sungai [27]. Kelompok kedua dari pemrakarsa industri, para pemrakarsa industri diharuskan bertanggung jawab terhadap segala proses yang ada di industri termasuk pembuangan limbah yang ada [28]. Pemrakarsa industri diharuskan memiliki dokumen izin lingkungan baik berbentuk proper, atau sistem manajemen lingkungan sebagai tolak ukur dalam pencegahan dan pengendalian lingkungan. Kelompok ketiga adalah pemerintah, pemerintah bertanggung jawab memberikan sanksi pada pemrakarsa industri jika terjadi pelanggaran pencemaran air sungai akibat proses produksi [29]. Pemerintah juga bertanggung jawab dalam memfasilitasi masyarakat untuk membuat IPAL komunal atau terpadu jika dalam suatu kelompok masyarakat belum memiliki IPAL [30].

\section{Kesimpulan}

Penelitian ini dilakukan untuk memberikan gambaran kondisi sungai di Indonesia terhadap daya tampung beban pencemaran sungai. Adapun sungai yang dimasukan dalam kajian literatur ini dan sudah tidak memiliki daya tampung beban pencemaran adalah sungai Code Yogyakarta; daerah aliran sungai Bengawan Solo segmentasi Kota Surakarta dan Kabupaten Karanganyar; sungai Brantas ruas Kota Malang; sungai Kupang Kota Pekalongan; sungai Mahakam Provinsi Kalimantan Timur; sungai brantas ruas Kekep-Punden Kota Batu: sungai Winongo Kabupaten Sleman; sungai Pesanggrahan segmen Kota Depok; sungai Garang Jawa Tengah; dan sungai Badung, Kota Denpasar.

Parameter yang paling banyak melampaui daya tampung beban pencemaran dari keseluruhan sungai adalah BOD, COD, TSS, nitrit, nitrat, fosfat dan amonia. Sebagian besar pada sungai tidak teridentifikasi sumber pencemarannya (sumber pencemaran tertentu dan tak tentu). Umumnya upaya pengelolaan sungai tidak dilakukan dengan optimal untuk menjaga kualitas air dan status mutu air sungai.

\section{Referensi}

[1] Badan Pusat Statistik, "Statistik Lingkungan Hidup Indonesia Air dan Lingkungan 2020," BPS Indonesia, katalog 3305001, 2020.

[2] Peraturan Pemerintah, "Peraturan Pemerintah Republik Indonesia Nomor 22 Tahun 2021 tentang Penyelenggaraan Perlindungan dan Pengelolaan Lingkungan Hidup," Pemerintah Republik Indonesia, 2021.

[3] P. G. R. Irsanda, Karnaningroem, D. Bambang, "Analisis Daya Tampung Beban Pencemaran Kali Pelayaran Kabupaten Sidoarjo Dengan Metode Qual2kw," J. Teknik ITS, 3(1), hal. D47-D52, 2014.

[4] N. Lusiana, A. A. Sulianto, L. A. Devianto, S. Sabina, "Penentuan Indeks Pencemaran Air dan Daya Tampung Beban Pencemaran Menggunakan Software QUAL2Kw (Studi Kasus Sungai Brantas Kota Malang)," J. Wilayah dan Lingkungan, vol. 8 (2), 2020. 
[5] Kementerian Lingkungan Hidup, "Pedoman Penetapan Daya Tampung Beban Pencemaran Air pada Sumber Air," Jakarta, 2003.

[6] N. Marlina, W. Brontowiyono, R. Chasna, "Analisis Kualitas Air dan Daya Tampung Sungai dengan Metode QUAL2Kw (Studi Kasus: Sungai Code, Yogyakarta)," J. Serambi Engineering, vol. 5(4), 2020.

[7] T. Dani, Suripin, Sudarno, "Analisis Daya Tampung Beban Cemar di DAS Bengawan Solo Segmen Kota Surakarta dan Kabupaten Karanganyar dengan Model QUAL2Kw," J. Ilmu Lingkungan, vol. 13(2): 92-102, 2015.

[8] H. A. Fajaruddin, M. Sholichin, B. T. Prayogo, "Studi Penentuan Daya Tampung Beban Pencemaran Sungai Brantas Ruas Kota Malang dengan Menggunakan Paket Program QUAL2Kw," J. Mahasiswa Jurusan Teknik Pengairan, vol. 1 (2), 2019.

[9] S. A. D. Pohan, Budiyono, Syafrudin, "Analisis Kualitas Air Sungai Guna Menentukan Peruntukan di Tinjau dari Aspek Lingkungan," J. Ilmu Lingkungan, vol. 4 (2), 2016.

[10] Y. Jumiati, Mislan, K. Subagiada, "Studi Penentuan Daya Tampung Beban Pencemaran Kualitas Air Sungai Mahakam Menggunakan Metode QUAL2Kw," J. Geosains Kutai Basin, vol. 3(1), 2020.

[11] Dinas Lingkungan Hidup Kota Batu, "Laporan Analisa Data Kualitas Air Sungai di Provinsi Jawa Timur Kota Batu Tahun 2015”, DLH-Kota Batu Malang, 2015.

[12] V. A. Richa, R. Haribowo, T. B. Prayogo, "Studi Penentuan Daya Tampung Beban Pencemaran Hulu Sungai Brantas Ruas Kekep-Punden Kota Batu dengan Menggunakan Aplikasi QUAL2Kw," J. Mahasiswa Jurusan Teknik Pengairan, vol. 1 (1), 2017.

[13] N. Marlina, Kasam, A. Juliani, "Evaluasi Daya Tampung terhadap Beban Pencemaran Menggunakan Model Kulitas Air (Studi Kasus: Sungai Winongo," J. Inovasi dan Kewirausahaan, vol. 4 (2), 2015.

[14] M. Komarudin, S. Hariyadi, B. Kurniawan, "Analisis Daya Tampung Beban Pencemaran Sungai Pesanggrahan," J. Pengelolaan Sumberdaya Alam dan Lingkungan, vol. 5 (2), 2015.

[15] G. Trilaksono, Sudarno, D. S. Handayani, "Studi Penentuan Daya Tampung Beban Pencemaran Air Sungai Melalui Pendekatan Software QUAL2E dan Metode Neraca Massa (Studi Kasus: Sungai Garang, Jawa Tengah)," Program Studi Teknik Lingkungan FT UNDIP, 2014.

[16] Putri, W.A.E., Purwiyanto A.I.S., Fauziyah, Agustriani, F., Suteja, Y., "Kondisi Nitrit, Nitrat, Amonia, Fosfat, dan BOD di Muara Sungai Banyuasin, Sumatera Selatan", J.Ilmu dan Teknologi Kelautan Tropis, volume 11 nomor 1, 2019.

[17] Zhang, J.Y., W.M. Ni., Y.M. Zhu, and Y.D. Pan., "Effects of different nitrogen species on sensitivity and photosynthetic of three common freshwater diatoms", Aquat Ecol., 47:25-35, 2012.

[18] Simbolon, A.R., "Pencemaran Bahan Organik dan Eutrofikasi di Perairan Cituis, Pesisir Tangerang", J.Pro-Life, volume 3 nomor 2, 2016.

[19] Baherem, "Strategi Pengelolaan Sungai Berdasarkan Daya Tampung Beban Pencemaran dan Kapasitas Asimilasi," Studi Kasus: Sungai Cibanten Provinsi Banten, J. Pengelolaan Sumberdaya Alam dan Lingkungan, Vol. 4 No. 1: 60 -69, 2014.

[20] Agustiningsih D., Sasongko S.B., Sudarno, "Analisis Kualitas Air dan Strategi Pengendalian Pencemaran Air Sungai Blukar Kabupaten Kendal”, J.Presipitasi, volume 9 nomor 2, 2012.

[21] Sara, P. S., Astono, W., Hendrawan, D.I., "Kajian Kualitas Air di Sungai Ciliwung dengan Parameter BOD dan COD”, Seminar Nasional Cendekiawan ke-4, 2018.

[22] Rahmawati, D., "Pengaruh Kegiatan Industri Terhadap Kualitas Air Sungai Diwak di Bergas Kabupaten Semarang dan upaya pengendalian pencemaran air sungai", $T$ Technology > TC Hydraulic engineering, Ocean engineering, 2011.

[23] Santiari, M., Nuarsa, I. W., Suyasa, I.W.B., "Penetapan Daya Tampung Beban Pencemaran Sungai Badung di Desa Pamogan", Ecotrophic : J.Ilmu Lingkungan (Journal of Environmental Science), volume 10 nomor 2, 2016.

[24] Ariyani, N., Ariyanti, D.O., Ramadhan, M., "Pengaturan Ideal tentang Pengelolaan Daerah Aliran Sungai di Indonesia (Studi di Sungai Serang Kabupaten Kulon Progo)", J.Hukum Ius Quia Iustum, volume 27 isu 3, 2020.

[25] Penyusun, Tim., " Rencana Pengelolaan Daerah Aliran Sungai Serang Tahun 2012- 2027", Kementerian Lingkungan Hidup dan Kehutanan Direktorat Jenderal Pengendalian Daerah Aliran Sungai dan Hutan Lindung Balai Pengelolaan Daerah Aliran Sungai dan Hutan Lindung Serayu, Opak, Progo, 2017. 
[28] Adi Susetyaningsih, "Pengaturan Penggunaan Lahan di Daerah Hulu Das Cimanuk Sebagai Upaya Optimalisasi Pemanfaatan Sumberdaya Air," J.Konstruksi Sekolah Tinggi Teknologi Garut, volume 10 nomer 1, 2012.

[29] H. Satriawan, "Strategi Pengelolaan Daerah Aliran Sungai (DAS) Dalam Rangka Optimalisasi Kelestarian Sumberdaya Air (Studi Kasus DAS Peusangan Aceh)", Majalah Ilmiah Universitas Almuslim, volume 9 (Edisi Khusus Dies Natalies), 2017.

[30] Pratama, K.N., Murtilaksono, K., Hendrayanto, "Pengembangan Kelembagaan Penggunaan Lahan Di Das Catur Kabupaten Madiun,” J.Tataloka, volume 19 nomor 2, 2017. 